\section{International Scientific Journal Theoretical \& Applied Science}

p-ISSN: 2308-4944 (print) e-ISSN: 2409-0085 (online)

Year: $2017 \quad$ Issue: 12 Volume: 56

Published: $19.12 .2017 \quad$ http://T-Science.org
Denis Chemezov

M.Sc.Eng., Corresponding Member of International Academy of Theoretical and Applied Sciences, Lecturer of Vladimir Industrial College, Russian Federation chemezov-da@yandex.ru

SECTION 2. Applied mathematics. Mathematical modeling.

\title{
CALCULATION OF PRESSURE LOSSES OF LIQUID AT A CYLINDRICAL STRAIGHT PIPELINE SECTION
}

Abstract: Results of a computer simulation of liquid flow and a calculation of resulting pressure loss at a cylindrical straight pipeline section are presented in the article. It is determined that pressure drop at an inlet and an outlet of the cylindrical straight pipeline section by a length of $1000 \mathrm{~mm}$ is $26 \%$.

Key words: liquid, velocity, pressure, length, flow.

Language: English

Citation: Chemezov D (2017) CALCULATION OF PRESSURE LOSSES OF LIQUID AT A CYLINDRICAL STRAIGHT PIPELINE SECTION. ISJ Theoretical \& Applied Science, 12 (56): 19-22.

Soi: http://s-o-i.org/1.1/TAS-12-56-5 Doi: crossef https://dx.doi.org/10.15863/TAS.2017.12.56.5

\section{Introduction}

Hydraulic resistances in pipelines lead to significant hydraulic losses. These losses are caused by a change of a direction and velocity of liquid flow at a certain length of the pipeline $[1-3]$. The constant direction of liquid flow is observed across entire a transverse section of the straight pipeline. However, variable velocity of liquid in different layers of flow (laminar and partially transitional flow) leads to the change of hydraulic pressure of fluid, and thus to an increase of energy costs on pumping liquid [4 - 8]. The change of hydraulic pressure and velocity of liquid flow at an inlet and an outlet of the pipeline can be determined by analytical formulae, measuring of pressure drop by special measuring instruments and a computer simulation (calculation) in special engineering programs subject to initial conditions of the researched process. The detailed change of velocity of liquid flow at the length of the straight pipeline advisable to consider by the results of the computer simulation.

\section{Materials and methods}

The calculation of pressure losses of liquid at the cylindrical straight pipeline section was performed in the Flow Simulation software environment.

A solid model of the straight pipeline section was built in the SolidWorks software environment. An inner diameter of the model was adopted by 30 $\mathrm{mm}$, a wall thickness is $5 \mathrm{~mm}$ and the total length of the pipeline section is $1000 \mathrm{~mm}$. Steel was selected by material of the pipeline section. The solid model of the cylindrical straight pipeline section is presented in the Fig. 1.

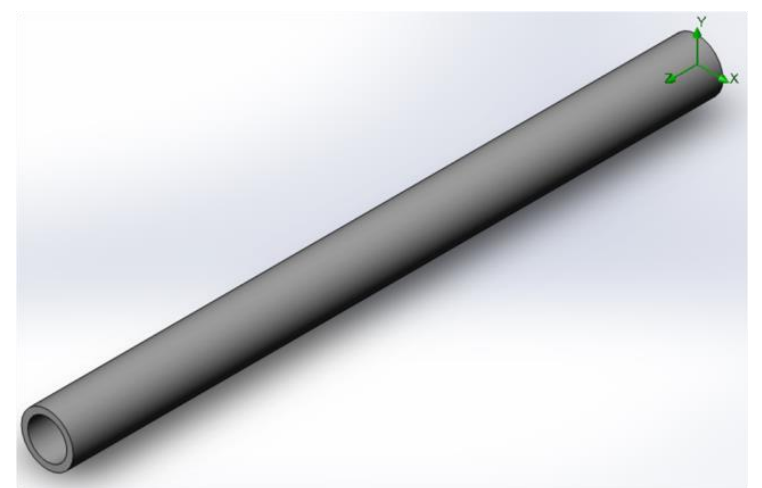

Figure 1 - The solid model of the straight pipeline section. 


\begin{tabular}{|c|c|c|c|c|c|c|}
\hline Impact Factor: & $\begin{array}{l}\text { ISRA (India) } \\
\text { ISI (Dubai, UAE } \\
\text { GIF (Australia) } \\
\text { JIF }\end{array}$ & $\begin{array}{r}=1.344 \\
=0.829 \\
=0.564 \\
=1.500\end{array}$ & $\begin{array}{l}\text { SIS (USA) } \\
\text { PИНЦ (Russia) } \\
\text { ESJI (KZ) } \\
\text { SJIF (Morocco) }\end{array}$ & $\begin{array}{l}=0.912 \\
=0.207 \\
=4.102 \\
=2.031\end{array}$ & $\begin{array}{l}\text { ICV (Poland) } \\
\text { PIF (India) } \\
\text { IBI (India) }\end{array}$ & $\begin{array}{l}=6.630 \\
=1.940 \\
=4.260\end{array}$ \\
\hline
\end{tabular}

For implement of the simulation of liquid flow it was adopted by the task type "Internal", since a calculated area was a volume of a channel of the pipeline section. Cavity of the pipeline section without flow conditions was excluded from the calculation. Orientation of the solid model of the pipeline section was carried out in the global coordinate system.

The model of the straight pipeline section was split into the following finite elements: partial cells 3760 , solid cells -528 , fluid cells -3264 . The total number of the finite elements was amounted to 7552 . The calculated number of the finite elements along the axes $\mathrm{X}$ and $\mathrm{Y}$ was amounted to 4 , along the axis $\mathrm{Z}$ was amounted to 66 . At set parameters of splitting of the solid model, accuracy of the obtained results was amounted to 3 . The values of minimum gap and minimum wall thickness were adopted by default.

As fluid was adopted by water at a temperature of 293.20 K. For a set temperature, density of water is $997.56 \mathrm{~kg} / \mathrm{m}^{3}$. Laminar and turbulent flow types of liquid at the straight pipeline section with an adiabatic wall were considered. Roughness of the inner wall of the straight pipeline section is 0 micrometer. Development of turbulent liquid flow in the pipeline was occurred at the length of $8 \times 10^{-4} \mathrm{~m}$ when turbulence intensity of $2 \%$. Mass flow rate at the inlet of the straight pipeline section was adopted by $0.45 \mathrm{~kg} / \mathrm{s}$. At the outlet of the straight pipeline section was acted normal atmospheric pressure (static pressure is $101325 \mathrm{~Pa}$ ).

The set calculation control options: maximum travels -4 , analysis interval -0.5 , refinement disabled.

\section{Results and discussion}

The velocity change of liquid flow at the length of the straight pipeline section (transverse section) is presented in the Fig. 2.

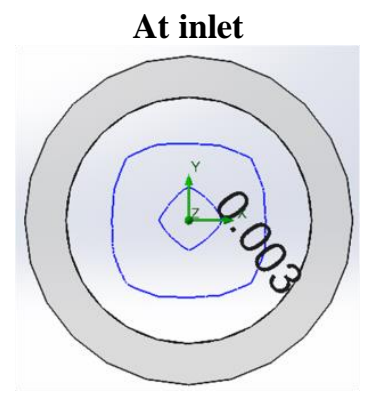

$\rightarrow(1)$

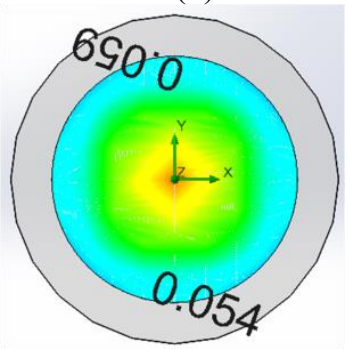

$\leftarrow(8)$

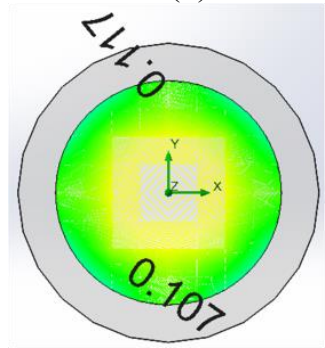

$\rightarrow(9)$

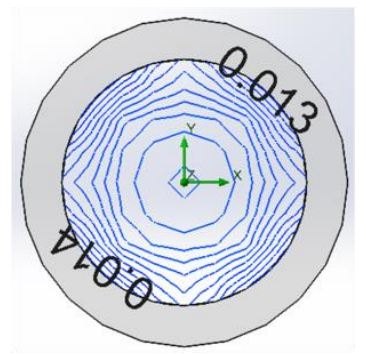

$\rightarrow(2)$

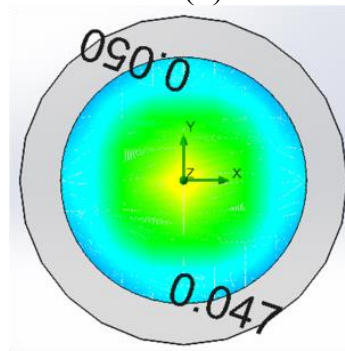

$\leftarrow(7)$

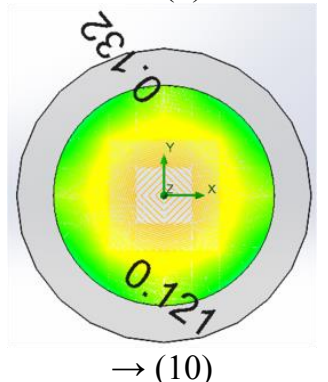

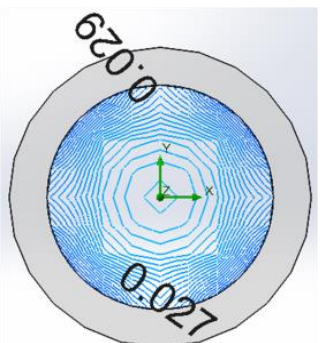

$\rightarrow(3)$

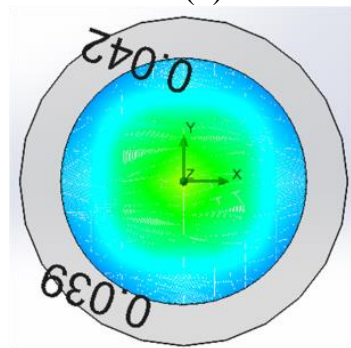

$\leftarrow(6)$

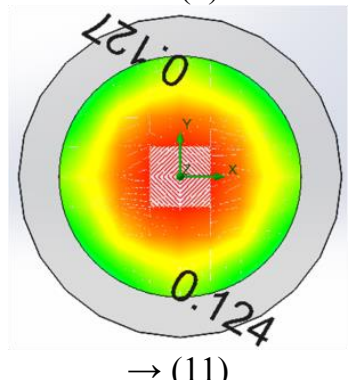

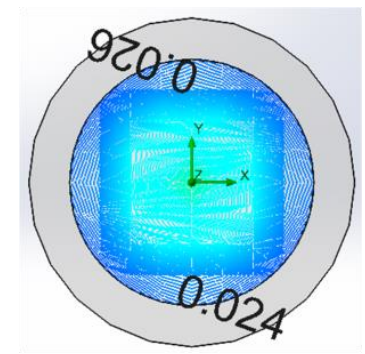

$\rightarrow(4)$

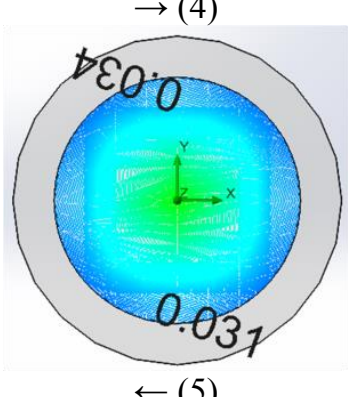

$\leftarrow(5)$

Figure 2 - The velocity fields of liquid flow across entire the length of the straight pipeline section. The unit of measurement of flow velocity is $\mathrm{m} / \mathrm{s}$.

In the figure - (1) corresponds by the velocities field of liquid flow at the inlet of the straight pipeline section, (2) is the velocities field at the distance of
$100 \mathrm{~mm}$ from the inlet, (3) is the velocities field at the distance of $200 \mathrm{~mm}$ from the inlet, (4) is the velocities field at the distance of $300 \mathrm{~mm}$ from the

ISPC Generalization of scientific results, 


\begin{tabular}{|c|c|c|c|c|c|c|}
\hline Impact Factor: & $\begin{array}{l}\text { ISRA (India) } \\
\text { ISI (Dubai, UAE } \\
\text { GIF (Australia) } \\
\text { JIF }\end{array}$ & $\begin{array}{r}=1.344 \\
=0.829 \\
=0.564 \\
=1.500\end{array}$ & $\begin{array}{l}\text { SIS (USA) } \\
\text { PИНЦ (Russia) } \\
\text { ESJI (KZ) } \\
\text { SJIF (Morocco) }\end{array}$ & $\begin{array}{l}=0.912 \\
=0.207 \\
=4.102 \\
=2.031\end{array}$ & $\begin{array}{l}\text { ICV (Poland) } \\
\text { PIF (India) } \\
\text { IBI (India) }\end{array}$ & $\begin{array}{l}=6.630 \\
=1.940 \\
=4.260\end{array}$ \\
\hline
\end{tabular}

inlet, (5) is the velocities field at the distance of 400 $\mathrm{mm}$ from the inlet, (6) is the velocities field at the distance of $500 \mathrm{~mm}$ from the inlet, (7) is the velocities field at the distance of $400 \mathrm{~mm}$ from the outlet, (8) is the velocities field at the distance of 300 $\mathrm{mm}$ from the outlet, (9) is the velocities field at the distance of $200 \mathrm{~mm}$ from the outlet, (10) is the velocities field at the distance of $100 \mathrm{~mm}$ from the outlet and (11) is the velocities field at the outlet of the straight pipeline section.

At the distance of $300 \mathrm{~mm}$ from the inlet of the straight pipeline section, velocity of liquid flow uniformly increases throughout the transverse section. In considering the plots (5) - (10) it can be concluded that the layers of liquid, located closer to the axis of the straight pipeline section, are moved with higher velocity than the upper layers. At the outlet of the straight pipeline section, velocity of liquid flow was amounted to $0.213 \mathrm{~m} / \mathrm{s}$ (contours of red color on the corresponding plot). Significant drop of static liquid pressure was determined at $1 / 3$ of the length of the straight section to the outlet opening of the pipeline.

Vorticity intensity of liquid flow at entire the length of the straight pipeline section can be presented in the Fig. 3.

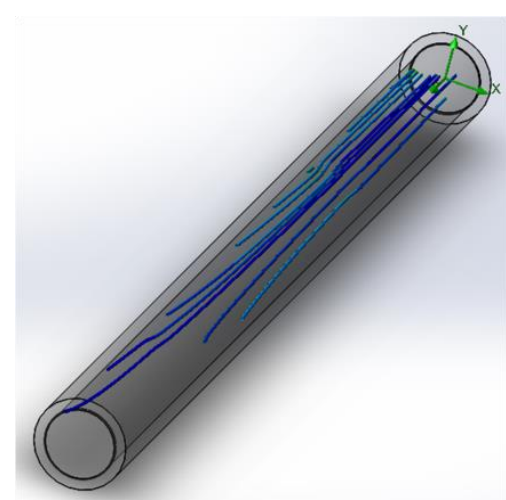

A

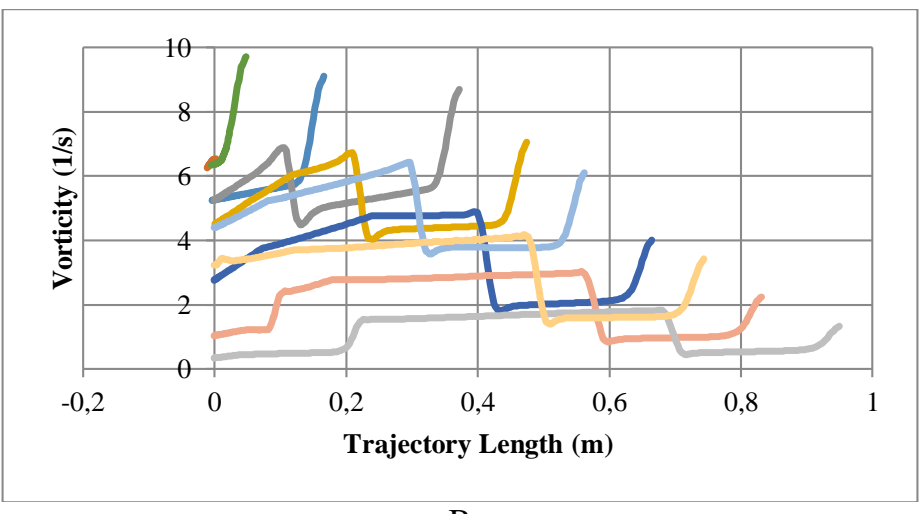

B

Figure 3 - Vorticity intensity of liquid flow: A - the model of the straight pipeline section with the calculated trajectories of vorticity, B - the dependencies of vorticity from the length of the straight pipeline section.

The length of the calculated trajectory of turbulent liquid flow on the model of the straight pipeline section corresponds to the length of the particular dependence in the graph. In accordance with the graph of dependence it is determined that the highest vorticity intensity is observed in the layers of liquid located close to the inner wall. This liquid flow is observed at $1 / 2$ of the length of the straight pipeline section from the side of the inlet opening.

The change of average static liquid pressure at the inlet and at the outlet of the straight pipeline section is presented in the Fig. 4.

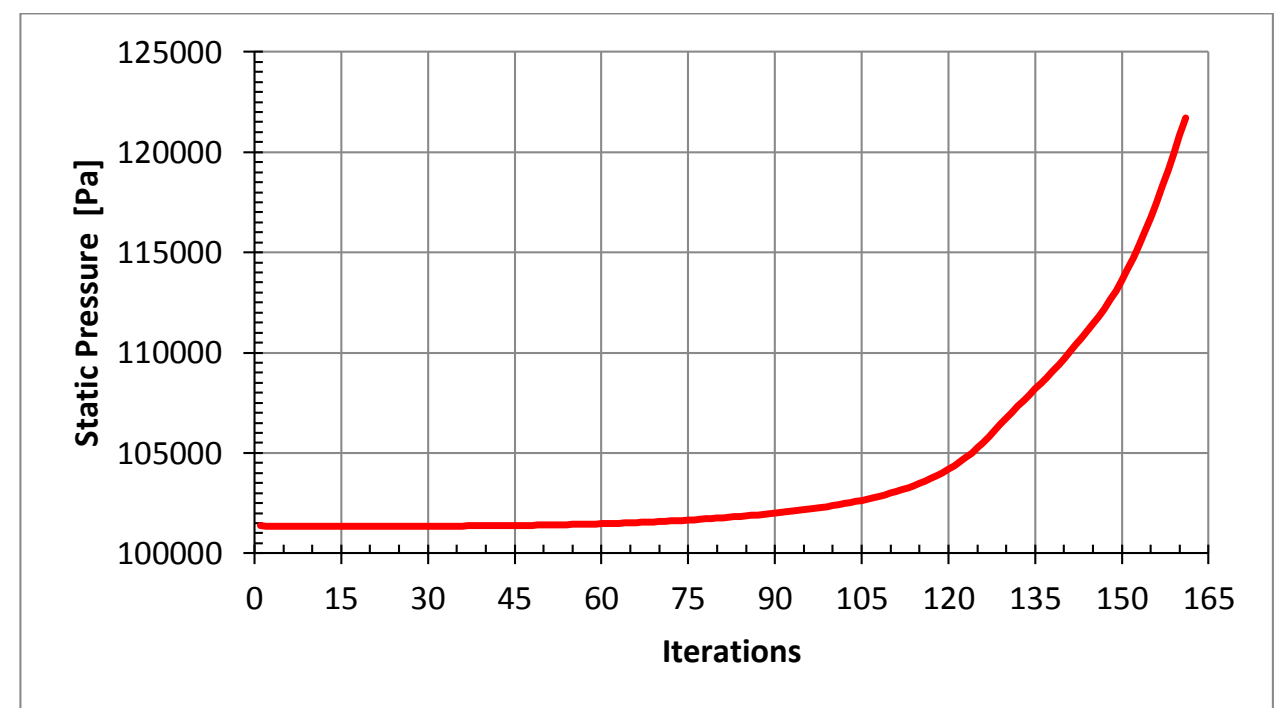

Figure 4 - The dependence of average static liquid pressure at the length of the straight pipeline section from the number of iterations. 
Hydraulic liquid pressure at the inlet of the straight pipeline section was amounted to 127503.98 $\mathrm{Pa}$, at the output hydraulic liquid pressure was amounted to $101325 \mathrm{~Pa}$. Pressure drop at the inlet and at the outlet of the straight pipeline section was amounted to $26 \%$. The results of calculation of the average value of static liquid pressure at the straight pipeline section are presented in the table 1 [9].

Table 1

The results of calculation of the average value of static liquid pressure at the straight pipeline section.

\begin{tabular}{|c|c|c|c|c|c|}
\hline Name & Unit & Value & Progress & Delta & Criteria \\
\hline Static Pressure & $\mathrm{Pa}$ & 121720.95 & 5 & 7780.55083 & 382.606315 \\
\hline
\end{tabular}

\section{Conclusion}

Thus, it is determined that at the straight pipelines sections of the short length (no more than $300 \mathrm{~mm}$ ) the change of static liquid pressure is practically not observed. Herewith, vorticity intensity of liquid flow at this length of the straight pipeline section is maximum. Constancy of the trajectory of liquid flow at the straight pipeline section doesn't guarantee maintaining of initial static pressure at the outlet. Pressure drop at the inlet and at the outlet of the straight pipeline section by the length of 1000 mm was amounted to $26 \%$.

\section{References:}

1. Chemezov DA, Tyurina SI, Bayakina AV, Goremykin VV (2014) Fluid transients flow in piping elbow. ISJ Theoretical \& Applied Science $12 \quad$ (20): 4-8. Doi: http://dx.doi.org/10.15863/TAS.2014.12.20.2

2. Chemezov D (2016) The character of the fluid flow in the pipelines with the local hydraulic resistances. ISJ Theoretical \& Applied Science, 12 (44): 62-68. Soi: http://s-o-i.org/1.1/TAS-1244-13

Doi: http://dx.doi.org/10.15863/TAS.2016.12.44.13

3. Chemezov D (2017) The finite element modeling of the fluid flow in the pipelines with the complex local hydraulic resistances. ISJ Theoretical \& Applied Science, 01 (45): 14-38. Soi: http://s-o-i.org/1.1/TAS-01-45-4 Doi: https://dx.doi.org/10.15863/TAS.2017.01.45.4

4. Chemezov D, Palev N (2016) Analytical models of the turbulent fluid flow in a circular pipe. ISJ Theoretical \& Applied Science, 09 (41): 77-84. Soi: http://s-o-i.org/1.1/TAS-0941-12

Doi: http://dx.doi.org/10.15863/TAS.2016.09.41.12

5. Chemezov D, Bayakina A (2016) The simulation of the fluid flow on the inner wall of the circular pipe. ISJ Theoretical \& Applied Science, 10 (42): 1-3. Soi: http://s-oi.org/1.1/TAS-10-42-1 Doi: http://dx.doi.org/10.15863/TAS.2016.10.42.1

6. Chemezov DA, Frolov VS, Fekhretdinov RR (2014) Simulation of deformation process and stress of a pipe wall operating in a test mode. Future of science - 2014 [Text]: Collection of scientific articles of the International scientific conference, Volume 3, South-West State University, Kursk. - pp. 176-180. ISBN 978-59905633-1-5.

7. Chemezov DA (2014) Hydrodynamic characteristics of water flow in straight and curved sections of a pipeline. Modern materials, equipment and technology [Text]: Materials of the $4^{\text {th }}$ International scientific and practical conference, South-West State University, CJSC «University book», Kursk. - pp. 468 - 471. ISBN 978-5-9906195-4-8.

8. Chemezov DA, Kukhar' NA, Kovalenko NO (2015) Fluid flow in a steel tubular coil (distribution of pressure gradient). Modern tool systems, information technologies and innovations [Text]: Collection of scientific works of the XII ${ }^{\text {th }}$ International scientific and practical conference, Volume 4, South-West State University, Kursk. - pp. 243 - 247. ISBN 978-5-9906417-4-7.

9. Chemezov DA, Pesenko AV (2016) Accuracy of calculation of a turbulent fluid flow in the CFD module of the program COMSOL Multiphysics 5.1. Journal scientific and applied researches: scientific and practical journal, №10, Ufa. - pp. 29 - 31. ISSN 2306-9147. 